\title{
LETTERS OF HENRY DODGE TO GEN. GEORGE W. JONES.
}

EDITED BY DR. WILLIAM SALTER.

(Continued from page 223.)

IV.

Fort Leavenworth, Dec. 3, 1834.

Col. Geo, W. Jones, Iowa County, Michigan Ty.:

I avail myself of the opportunity of writing you by Augustus, who will be able to give you an outline of my movements last summer.

I have this moment received a letter informing me of the election of Dr. Linn to the Senate of the U.S. He will do everything in his power for the people of the Mining Country and will exert himself for his friends.

If the Territory (of Michigan) is divided, I want you appointed Brigadier General of the Militia. I will write the Secretary of War (Lewis Cass) on that subject. Do not fail to write to Lyon (Delegate to Congress from Michigan Territory). I have no doubt he will do all he can to retain the confidence of the people of the Mining Country. I wish my friends in the Mining Country to remain quiet on the subject of my appointment as Governor until you hear from me or Doctor Linn. The course of events will be closely watched at Washington. My old friends in the Mining Country will, I am sure, stand by me.

Should the Indians go to war with each other you may have some difficulty with them that will take me to that country. I have seen the publication in the last Republican (St. Louis newspaper), and if the statements are correct the Government will have to take steps to force the offenders to deliver up the murderers. I am drilling the dragoons here and my horses will be in fine order by spring. I feel a great desire to visit the Mining Country if my services are needed. I should prefer the upper country for the theatre of my operations where I could have my friends by my side.

\section{V.}

Fort Leavenworth, May 27, 1835.

Col. George W. Jones, Postmaster, Sinsinnewa Mound, Iowa County, Michigan Territory:

I leave this post on to-morrow on my tour to the West, and knowing you feel an interest in the expedition I give you a brief outline of my intended movements.

I will have with me about one hundred dragoons, well-armed and wellmounted. I shall take two light field-pieces that will be posted on the angles of my eamp at night, and will cover my march in erossing rivers 

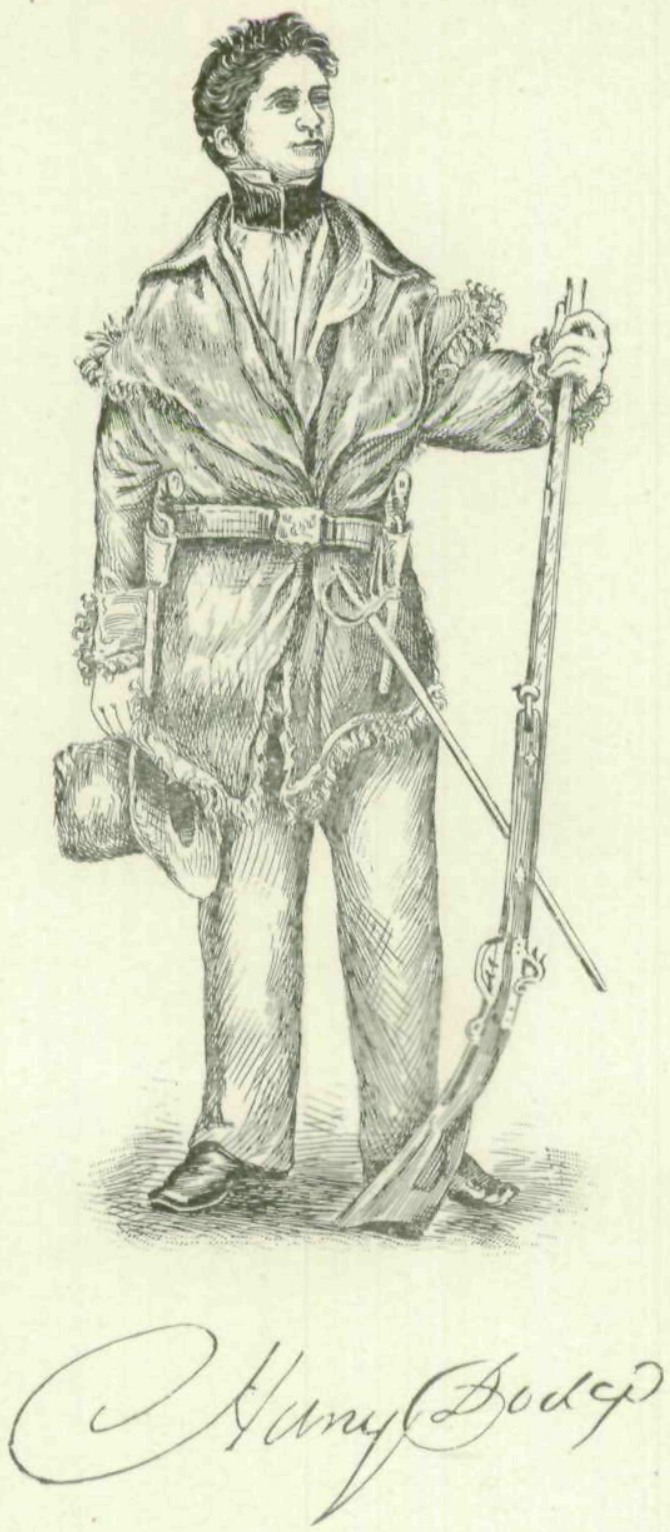

HENRY DODGE.

Colonel 1st U. S. Dragoons, 1833; Governor of Wisconsin Territory, 1836-41, and 1845-48; United States Senator from Wisconsin, 1849-57. Died at Burlington, Iowa, June 19, 1867. 
and difficult passes, should my mareh be obstrueted by the Indians. I will pass the different bands of Indians on the Platte, the Ottoes, Omahas, the Grand Pawnees, Pawnee Loups, and Pawnee Republicans, and expect to fall in with the Arickaras or Rees Indians; they occasionally kill the Americans when they meet them.

As I am straining my orders in going a much greater distance than is expected by the General-in-Chief, I must not fight the Indians, as the policy of the Government is entirely of a pacific character, unless the safety of my command is at stake and the success of the expedition is in question. In that event my motto will be Death or Victory. I never with my consent will survive a defeat by the Indians.

My route will be up the South Fork of the Platte to its head, and then a direct course to the Rocky Mountains. On reaching the Mountains I will shape my course to the Arkansas river. Between the Mountains and the head of that river, I am told by Major Daugherty who will accompany the expedition, I will meet bands of Arapahas, Cheyennes, and Black Feet Indians with the Snake Indians who live in the mountains. These Indians visit this part of the country to kill buffalo, and pass from the mountains to the south in large war-parties against the Southern Indians. After adjusting amicably, if I ean do so, our difficulties with these Indians, I will proceed down the Arkansas to near where the road crosses going to Santa $\mathrm{Fe}$, and expect to meet the Camanche and Kiowa Indians in this country. I will then return to this post.

I understand from Lt. Crossman you contemplate visiting Washington this winter. I hope to meet you there, and if I get my leave of absence in time I will visit the Mining Country on my way to Washington. If it is possible to make the arrangements, I would be pleased if my family could winter in that country with their friends during my absence. I would be glad to see the people of the country generally, and know their views and wishes with respect to public men and measures. I hope to see them enjoying the advantages of a free Government as well as the natural resources the country presents to them. I would prefer a residence in that country free of all public employment, if my circumstances would permit. My cireumstances in a pecuniary point of view forbid that indulgence. I do not know what the views and feelings of my friends may be; I am disposed to be advised by them. Perhaps a silent course would be the most prudent one on the subject of the appointment of Governor. The present position of the Territory of Michigan is such that she must be admitted a State this session of Congress, and the new Territory must then be formed west of Lake Michigan, if created at all.

VI.

Henry Dodge had been foremost as early as 1829 in advocating a division of Michigan Territory and the organization of a separate Territory west of Lake Michigan. His reasons for it were addressed to Austin E. Wing, then Dele- 
gate to Congress from Michigan Territory, in a paper of great force, which is preserved in Smith's History of Wisconsin, Vol I, pp. 430-2.

Pursuant to an act of the Legislative Council of Michigan Territory August 23, 1835, an election for Delegate to Congress was held on the first Monday of October following in that part of the Territory which was not included within the new State of Michigan. This was the first election to a national office in what is now the State of Iowa. There had been an election the previous year, 1834; but it was for county officers only. George W. Jones was nominated as a candidate for delegate to Congress by Augustus C. Dodge at a meeting held at Mineral Point, Iowa county, in May, 1835. On the day of the election Col. Jones was in Burlington, and long afterwards mentioned it with pride that of two hundred or more votes polled there only six were against him. His principal competitor was James D. Doty, of Green Bay, between the people of which place and those of the "Mining Country" there was a jealousy as to the location of the seat of government for the contemplated new Territory. Col. Jones was elected and took his seat upon the assembling of Congress, December 7, 1835.

Fort Leavenworth, Nov, 25, 1835.

Col. George W. Jones, Delegate to Congress, Washington:

I sincerely congratulate you on your election and the defeat of Doty who has been doubly distanced in the race. You know the wants and wishes of the people who have elected you, and no doubt will do everything in your power to represent them truly. I was much pleased that my sons and friends united in your support. Doty was not deserving of the confidence of the people of the Mining Country. During the time he represented them in the Couneil he was constantly exerting himself for Green Bay because he was the owner of property at that place; I think him a selfish, illiberal minded politician who goes for himself alone, and he thinks he has talent and tact to deceive others.

I know nothing of the political parties in Michigan; one thing is certain that the people have been completely justifiable in the course they have taken. Their numbers at sixty thousand would have enabled them to form a Constitution, and they have a right to admission as a member of the Union. I hope the members elect to the Senate, and the member of the lower House, and as well the Delegate-elect west of Lake Michigan, will be 
permitted by Congress to take their seats without being delayed a whole session, as was the case on the admission of Missouri.

As respects my appointment as Governor of the new Territory I will frankly say to you, I am desirious to return to my friends and make that country my home, and if it is the wish of the people will serve them as Governor.

I know, my dear friend, your kind feelings toward me and that you sincerely wish my appointment. You are representing the whole of the people west of Lake Michigan. There has been a great accession of population since $I$ left that country, and unless you are confident my appointment will be in accordance with the wishes of the people you would do them and yourself as their Representative an act of injustice by supporting me. I hope you will consult my friends, Doctor Linn and General Ashley, on any steps that may be taken. The most perfect understanding and concert of action may be necessary to succeed. There will no doubt be many applicants for the appointment. Should Lyon or Wing be elected from the new State to the Senate, unless they have promised their support to some other applicant, I think they will be in favor of my appointment. From Governor Horner's going at so late a period to Michigan to settle the existing difficulties between Ohio and Michigan, I was under the impression he would be an applicant for the office of Governor of the new Territory.

I have been detained here attending a General Court Martial, and it will perhaps be March before I can start for Washington.

VII.

William S. Hamilton was a son of Alexander Hamilton, first Secretary of U. S. Treasury. Capt. Matthew Duncan was a brother of Joseph Duncan, Governor of Illinois, 1834-8. Judge David Irvin was one of the judges of Michigan Territory, appointed by President Jackson in 1832. He was appointed one of the associate judges of Wisccnsin Territory in 1836, and in that capacity held court in Dubuque and Des Moines counties. Dr. Moses Meeker was characterized by Lyman C. Draper as "one of the noblest of the band of Wisconsin pioneers." Major Charles F. Legate was a Government surveyor; died at Mineral Point, January 14,1874 .

Fort Leavenworth, Dee. $7,1835$.

Col. Geo. W. Jones, Delegate to Congress, Washington:

Your esteemed favor of the 14 th ult. from St. Genevieve I received yesterday, Mr. Hamilton was wrong in stating to you that the President (Andrew Jackson) had ordered me to repair to, Washington after the trial of Capt. Duncan. My leave of absence has been transmitted to General Gaines, 
and will have to be sent by him to the General Headquarters of the army for approval before I can leave this post.

I noticed that Judge Irvin and Moses Meeker had been selected by a small meeting at Mineral Point to repair to Washington to act as special agents for the miners for the purpose of obtaining pre-emption rights for their mineral lots; I then suspected Judge Irvin of wanting to give himself consequence in the formation of the new Territory. I thought his object was the appointment of Chief Justice, and that he could hardly be so ambitious as to aim at the office of Governor.

You have been elected by a large majority of the eitizens west of Lake Michigan to represent their wants and wishes, and any attempt on the part of these special agents or any other person to interfere with duties that properly belong to you would be unjust and wrong. You have a right to expect the aid and support of the Government in sustaining such measures as have for their object the good of those who have confided their rights to your charge. Be assured you have my most entire confidence as a friend, and you have a right to expect the aid and assistance of my friends in sustaining the wishes of the people. I am sure you will be warmly supported by them.

The best energies of my life have been spent in the Mining Country. The great mass of the people of that Country are my friends, and the gratitude I know they feel for my humble services is more gratifying to me than any public station that could be conferred on me. If it is their wish, however, that I should be their Governor I will honestly serve them to the best of my abilities, and retire from the Army.

I hope you will be permitted to take your seat without difficulty. Judge Doty, if he can, will give you trouble, and unite with Judge Irvin to defeat you and prevent my appointment, if possible. Dr. Linn will watch the current of events, and in everything in relation to myself I wish you to consult him. If Major Legate is in Washington, he will be of great service to you; his intimate knowledge of the wants of the people you represent, and his high standing with the Government for integrity and truth will enable him to be serviceable to you and the mining interests.

\section{VIII.}

Fort Leavenworth, Jan. 6, 1836.

Col. Geo. W. Jones, House of Representatives, Washington:

I am rejoiced to hear you had no difficulty in taking your seat. I expected Judge Doty would give you all the trouble in his power, but I had no idea he would attack you by hand-bills at Washington. I have been much surprised at the conduct of Bracken (aid to Col. Dodge in the Black Hawk war, 1832). I knew he was always well stocked with impudence, but could never have believed that he would have exposed himself and have acted so much like a villain. You have had a complete triumph over your political opponents. Doty deserved defeat for his duplicity. The better part of the community will always know how to construe the actions of designing demagogues who go for themselves regardless of the rights of 
others, and the people will weigh them by the lever of public opinion.

My application for leave of absence has been forwarded to Washington. My services have been of so important a character since $I$ have been in the service of the U.S. that I think they will hardly refuse me.

Your constituents are deeply interested in the appointment of their Governor, Judges, and all the Federal officers. They require a Governor who has a knowledge of the character and wants of the people of the contemplated Territory; they are deeply interested in the selection of their Judges. The Secretary of the Territory is an office of the first importance; the Marshal is calculated to have a great influence, should he have much business: and if the provisions of the bill organizing the Territory gives the command of the militia to a Brigadier General appointed by the President, that is an appointment of importance in a territory so remote and exposed to the inroads of the Indians as yours will be. The location of the seat of Government is a subject of much interest to the people; if there could be a provision that the Council could select the place with the approbation of the Governor, it would be most satisfactory to the majority. In a Territorial government I am in favor of permitting the people to participate as far as practicable in the administration of affairs, and $I$ have always thought Territorial Governors have had more power than should be delegated to them.

I think if Mr. Lyon (U. S. surveyor at Prairie du Chien in 1828, where he made a survey of the private French land-claims, a visitor the same year at Henry Dodge's "Diggings" in the Mining Country; afterwards delegate to Congress from Michigan Territory; U.S. Senator from the State of Michigan, 1836-40) gets his seat in the Senate, knowing as he does the wants and wishes of the people between Lake Michigan and the Mississippi, that he will afford you all the aid in his power; and indeed he has no right to be unfriendly to my appointment as Governor of the new Territory. I have always been friendly to him. It is true I gave my vote for Mr. Wing as Delegate when he was a candidate. I had promised Wing at Washington before I knew Lyon was a candidate. I have always considered Lyon a man of promise and truth, and so expressed myself to Gen. Cass and others at Washington. I have entire confidence in the President and my friends, and will be satisfied with what they may do. It is one of the most cheering reflections of $\mathrm{my}$ life that $\mathrm{I}$ have retained the confidence and friendship of all those who have known me in early life, and those who best know me are my best friends.

\section{IX.}

Fort Leavenwonth, Jan. 28, 1836.

Col. George W. Jones, House of Representatives, Washington.

Nothing, I think, can prevent the establishment of a new Territory west of Lake Michigan the present session of Congress. The wants of the people, their numbers, and the necessity of a representation on the floor of Congress with the extension of our settlements west of the Mississippi, are strong claims that cannot be set aside. 
I would earnestly recommend that you have the bill for the Territorial Government shaped so as to have two Houses, a House of Representatives as well as a Legislative Council, to be elected by the people. It would be more consistent with the principles of republican government, and be more satisfactory to the people. I have often thought it a great omission in the Territorial Government of Michigan to have a Legislative Council alone, composed of only thirteen members.

The personal friendly feeling between Dr. Linn and the President will enable you to know how to act. I have been on the most intimate and friendly terms with General Ashley for thirty years, and I have never had a more true and consistent friend. I have the most entire confidence in the representation from Missouri, as well as many other friends I know I have in Congress. Col. Johnson (afterwards V. Pres. U. S.), I have every reason to believe, will do everything in his power for me. If I were to make a selection of my personal friends, three in whom I have as much confidence as any on earth, it would be Dr. Linn, Gen. Ashley, and yourself. Let things take what course they will, I am sure my friends will do me ample justice.

The Iowa Press.-There are now twenty newspapers published in Iowa, which is an increase of seven since The Statesman was started a little more than a year ago. Of the twenty, nine are democratic, eight whig, one liberty, one agricultural, and one religious. The press is rapidly finding its way into the great west, as the vast increase in this State for the last year indicates. There are twice as many now as there were in April, 1847, which is doubling in 17 months. Can any other State in the Union boast of as rapid an increase?-Iowa Statesman, Ft. Madison, September, 1848. 
Copyright of Annals of Iowa is the property of State of Iowa, by \& through the State Historical Society of Iowa and its content may not be copied or emailed to multiple sites or posted to a listserv without the copyright holder's express written permission. However, users may print, download, or email articles for individual use. 